\title{
PENGEMBANGAN BAHAN AJAR (LKS) BERGAMBAR MENULIS TEKS PROSEDUR KOMPLEKS SISWA MTS KELAS VIII MIFTAHUL ULUM PAMEKASAN MADURA
}

\author{
Sofiatun dan M. Ridlwan \\ SMK Matsaratul Huda Pamekasan Madura, Universitas Muhammadiyah Surabaya \\ fifinsofiatun7@gmail.com
}

\begin{abstract}
ABSTRAK
Tujuan dalam penelitian ini, yaitu (1) mendeskripsikan pengembangan LKS teks prosedur kompleks untuk siswa MTs kelas VIII, (2) Mendeskripsikan efektifitas LKS teks prosedur kompleks untuk siswa MTs kelas VIII, dan (3) Mendeskripsikan kepraktisan LKS teks prosedur kompleks untuk siswa MTs kelas VIII. Penelitian ini menggunakan metode penelitian dan pengembangan (R\&D), yaitu survei pendahuluan, awal pengembangan prototipe, desain produk, validasi produk, revisi desain, dan deskripsi hasil penelitian. Subjek penelitian ini adalah bahan ajar LKS menulis teks prosedur kompleks. Sumber data validasi prototipe bahan ajar adalah guru bahasa indonesia kelas VIII dan ahli bahan ajar. Dari kedua orang ahli bahan ajar yang menilai bahan ajar LKS menulis teks prosedur kompleks, yaitu (1) aspek penyajian sampul (cover) dalam kategori "Baik", (2) aspek isi/materi dari ahli bahan ajar mendapatkan skor rata-rata dalam kategori "Baik", (3) aspek kebahasaan dan keterbacaan mendapatkan skor rata-rata dalam kategori "Baik". Sedangkan dari ahli pengguna, dari (1) aspek sampul (cover) dari ahli pengguna mendapatkan skor rata-rata dalam kategori "Baik", (2) aspek Isi/materi ahli pengguna mendapatkan skor rata-rata dalam kategori "Baik", dan (3) aspek kebahasaan ahli pengguna mendapatkan skor rata-rata dalam kategori "Baik".
\end{abstract}

Kata Kunci: bahan ajar, lks, menulis, teks prosedur kompleks, siswa kelas VIII MTs

\section{ABSTRACT}

The objectives of this study are (1) to describe the development of complex procedure text LKS for class VIII MTs students, (2) To describe the effectiveness of complex procedure text LKS for class VIII MTs students, and (3) Describe the practicality of complex LKS text procedures for MTs class students VIII. This research uses research and development methods ( $R$ \& $D)$, namely preliminary surveys, initial prototype development, product design, product validation, design revision, and description of research results. The subject of this research is LKS teaching materials writing complex procedure texts. Data source validation of teaching material prototypes is Indonesian language teacher class VIII and teaching materials expert. Of the two teaching materials experts who assessed LKS teaching materials to write complex procedure texts, namely (1) aspects of the cover in the "Good" category, (2) the content / material aspects of the instructional materials expert 
got an average score in the category "Good", (3) linguistic aspects and readability get an average score in the "Good" category. Whereas from expert users, from (1) the cover aspects of the user's expert get an average score in the "Good" category, (2) the Content / material aspect of the user gets the average score in the "Good" category, and ( 3 ) expert language aspects users get an average score in the "Good" category.

Keywords: teaching material, LKS, write, complex prosedur text, student class VIII MTs

\section{PENDAHULUAN}

Kegiatan menulis tidak bisa lepas dari tiga kemampuan berbahasa lainnya, yakni menyimak, berbicara, dan membaca. Tarigan (2008:3) Menulis merupakan suatu kegiatan yang produktif dan ekspresif. Produktif berarti menghasilkan suatu produk tulisan dan ekspresif berarti mengungkapkan pikiran dan perasaan yang ada pada diri seseorang. Dalam setiap kegiatan menulis terdapat tujuan yang hendak dicapai. Salah satunya adalah memberi tahu mengenai sesuatu berupa arahan agar dapat dilakukan oleh orang lain dengan baik dan benar. Tujuan tersebut mengacu pada kegiatan menulis teks prosedur kompleks.

Kosasih (2009:26) Menulis juga merupakan salah satu aspek pengajaran bahasa, keterampilan ini sangat penting bagi siswa, baik selama mereka mengikuti pendidikan di sekolah maupun dalm kehidupan kelak di masyarakat. Keberhasilan siswa dalam mengikuti kegiatan belajar di sekolah banyak ditentukan oleh kemampuan dalam menulis. Oleh karena itu, pengajaran keterampilan menulis kedudukannya sangat penting dalam pendidikan.

Masalah yang muncul dalam keterampilan menulis teks prosedur kompleks dapat dipengaruhi oleh faktor internal siswa dalam pembelajaran di sekolah. Faktor internal merupakan faktor yang berasal dari diri siswa dalam pembelajaran di sekolah. Kurangnya pemahaman siswa tentang kalimat efektif menyebabkan siswa kurang mencapai nilai maksimal dalam keterampilan menulis teks prosedur kompleks. Siswa masih mengalami kesulitan dalam menyusun kalimat teks prosedur kompleks. Siswa kurang terampil dalam pemilihan kosa kata. Untuk mengatasi hal ini, guru harus lebih banyak memberikan penjelasan kepada siswa dengan memberikan contoh-contoh menulis teks prosedur. Siswa hanya menulis teks prosedur kompleks apabila ada pelajaran bahasa Indonesia dan jika mendapat tugas dari guru. Mereka menganggap bahwa menulis adalah pelajaran yang sulit karena tidak ada stimulus yang memberikan peningkatan menulis teks prosedur kompleks. Siswa mengalami kesulitan menulis terutama dalam penggunaan bahasa yang baik.

Selain itu, metode pembelajaran menulis teks prosedur kompleks di sekolah yang dilakukan oleh guru masih bergantung pada cara yang konvensional yaitu menggunakan metode ceramah. Metode ceramah masih sering digunakan dalam pelajaran menulis teks prosedur kompleks. Pada hakikatnya metode ceramah baik 
digunakan dalam pembelajaran karena materi dapat langsung diajarkan guru kepada siswa, tetapi lebih efektif apabila metode ceramah digabungkan dengan pembelajaran secara langsung (praktek).

Untuk itu, cara meningkatkan keterampilan menulis teks prosedur kompleks memberikan banyak kesempatan kepada siswa untuk menulis teks prosedur kompleks dengan menggunakan kalimat efektif yaitu membuat bahan ajar yang berbentuk LKS.

Lembar Kegiatan Siswa (LKS) merupakan suatu bahan ajar cetak yang berupa lembaran berisi tugas yang didalamnya berisi petunjuk, langkah-langkah untuk menyelesaikan tugas. Penciptaan produk untuk memberikan pemahaman dan keterampilan yang berbentuk LKS adalah sebuah lembar kerja siswa yang akan memberikan banyak kesempatan kepada siswa dalam menulis. Menurut (Sutanto, 2009:1) Lembar Kerja Siswa (LKS) merupakan materi ajar yang dikemas sedemikian rupa agar siswa dapat mempelajari materi tersebut secara mandiri.

Berdasarkan penjelasan tersebut, dapat disimpulkan bahwa pengembangan kemampuan menulis teks prosedur siswa MTs belum dapat dilakukan secara optimal. Oleh karena itu, diperlukan berbagai upaya untuk mewujudkan proses pengembangan kemampuan menulis teks prosedur kompleks secara lebih baik. Selain dengan cara melakukan strategi pembelajaran yang sesuai, upaya peningkatan kemampuan menulis teks prosedur kompleks siswa juga dapat dilakukan dengan cara penggunaan produk-produk pendidikan yang dapat menunjang pembelajaran menulis teks prosedur kompleks. Produk-produk pendidikan tersebut di antaranya adalah buku /LKS.

Penelitian ini bertujuan untuk mendeskripsikan efektifitas LKS teks prosedur kompleks untuk siswa MTs kelas VIII Miftahul ulum Pamekasan Madura. Produk yang akan dikembangkan berupa bahan ajar menulis teks prosedur kompleks dengan menggunakan bahan ajar LKS siswa kelas VIII MTs Miftahul Ulum Pademawu Pamekasan Madura mempunyai spesifikasi beberapa spesifikasi, yaitu (1) Bahan ajar yang akan dikembangkan berupa materi tentang menulis teks prosedur kompleks yang terdapat di buku paket atau LKS, (2) Buku paket atau LKS berisi materi tentang teks prosedur kompleks, (3) Pengembangan bahan ajar menulis teks prosedur kompleks ini diintegrasikan dengan menggunakan bahan ajar LKS.

Penelitian pengembangan bahan ajar juga pernah dilakukan oleh Fadlia (2011) dengan judul skripsi Pengembangan Bahan Ajar LKS Menulis Karangan Narasi dengan Pendekatan Kontekstual bagi Siswa Kelas X SMA. Penlitia Fadlia menghasilkan bahan ajar yang berbentuk LKS dalam membantu proses pembelajaran menulis karangan narasi. Setelah dilakukan peelitian, diperoleh data kebutuhan siswa dan guru terhadap bahan ajar menulis karangan narasi yang selanjutnya dirumuskan ke dalam prinsip-prinsip pengembangan bahan ajar, yaitu (1) siswa dan guru membutuhkan bahan ajar LKS menulis karangan narasi dengan pendekatan 
kontekstual, (2) materi disesuaikan dengan ke butuhan dan disertai dengan praktik menulis, (3) penyajian menarik dan mendorong siswa untuk aktif, dan (4) bentuk fisik LKS yang disesuaikan dengan kebutuhan siswa dan guru mulai dari judul buku hingga gambar/ilustrasi.

Penelitian yang dilakukan oleh Fadlia dengan peneliti memiliki persamaan dan perbedaan. Persamaannya terletak pada jenis penelitian, yaitu sama-sama penelitian pengembangan bahan ajar LKS menulis. Selain persamaan, penelitian yang dilakukan oleh Fadlia juga memiliki perbedaan dengan penelitian yang dilakukan peneliti. Perbedaannya terletak pada subjek dan sumber data penelitian. Fadlia mengembangkan bahan ajar LKS menulis karangan narasi, sedangkan peneliti akan mengembangkan bahan ajar LKS menulis teks prosedur kompleks. Bahan ajar LKS yang dikembangkan oleh Fadlia ditujukan untuk siswa SMA, sedangkan peneliti mengembangkan bahan ajar LKS untuk siswa MTs.

Sebuah bahan ajar juga harus memenuhi standar kelayakan. Standar kelayakan tersebut dapat dilihat dari isi, sajian, bahasa, dan grafika. Menurut muslich (2010) kelayakan isi memiliki tiga indikator yang harus diperhatikan, yaitu kesesuaian materi dengan standar kompetensi dan kompetensi dasar, keakuratan materi, dan materi pendukung pembelajaran. Kelayakan penyajian meliputi teknik penyajian, penyajian pembelajaran, dan kelengkapan penyajian. Dalam hal kelayakan bahasa, ada beberapa indikator yang harus diperhatikan, yaitu kesesuaian pemakaian bahasa dengan tingkat perkembangan siswa, pemakaian bahasa yang komunikatif, dan memenuhi syarat keruntutan dan keterpaduan alur berpikir. Kelayakan kegrafikan meliputi bentuk, desain kulit, dan desain isi.

Bahan ajar dalam penelitian ini memiliki karakteristik yang berbeda dengan bahan ajar yang lainnya. Bahan ajar dalam penelitian ini digunakan dalam mata pelajaran bahasa indonesia untuk siswa MTs kelas VIII. Bahan ajar disusun berdasarkan standar kompetensi dan kompetensi dasar dari kurikulum yang berlaku, yaitu menulis teks prosedur kompleks melakukan sesuatu dengan urutan yang tepat dan menggunakan bahasa yang efektif. Tujuan dari penyusunan bahan ajar ini agar siswa mampu mencapai tujuan pembelajaran. Keberhasilan pembelajaran dapat diukur melalui indikator yang dicapai.

Bahan ajar berorientasi kepada kegiatan belajar siswa sehingga bahan ajar disusun berdasarkan kebutuhan dan motivasi siswa. Hal ini bertujuan agar siswa lebih antusias dan lebih semangat dalam proses pembelajaran. Bahan ajar ini juga dapat digunakan siswa secara mandiri tanpa harus melibatkan guru. Bagi guru, bahan ajar ini hendaknya bisa mengarahkan guru dalam menentukan langkahlangkah pembelajaran dikelas. Pola sajian bahan ajar disesuaikan dengan perkembangan intelektual sehingga siswa mudah memahami pelajaran, dan bahan ajar yang dimaksud adalah LKS.

Lembar Kegiatan Siswa (LKS) merupakan suatu bahan ajar cetak yang berupa lembaran berisi tugas yang didalamnya berisi 
petunjuk langkah-langkah untuk menyelesaikan tugas berupa pilihan ganda dan essay. LKS dapat berupa panduan untuk latihan pengembangan aspek kognitif maupun panduan untuk pengembangan semua aspek pembelajaran dalam bentuk panduan eksperimen dan demonstrasi Purwoko (30:2013).

Tujuan pembelajaran menggunakan LKS yaitu melatih siswa berfikir lebih aktif dalam kegiatan belajar mengajar, LKS berfungsi sebagai pedoman guru dan siswa dalam melaksanakan proses kegiatan pembelajaran, LKS berisi pertanyaan atau isian yang jawabannya ada di dalam buku. Adapun manfaat menggunakan LKS dalam proses belajar mengajar yaitu akan membuka kesempatan kepada siswa untuk ikut aktif dalam pembelajaran, LKS memudahkan guru untuk melihat keberhasilan siswa dalam mencapai sasaran belajar, dan sebagai pedoman guru dan siswa dalam melaksanakan proses kegiatan pembelajaran.

Menulis merupakan salah satu keterampilan berbahasa yang dipergunakan dalam komunikasi secara tidak langsung. Keterampilan menulis didapatkan melalui proses belajar dan berlatih. Seseorang yang tidak pernah berlatih menulis akan mengalami kesulitan dalam menuangkan ide atau gagasan ke dalam tulisan.

Tujuan menulis adalah memproyeksikan sesuatu mengenai diri seseorang. Tulisan mengandung nada yang serasi dengan maksud dan tujuannya. Menulis tidak mengharuskan memilih suatu pokok pembicaraan yang cocok dan sesuai, tetapi harus menentukan siapa yang akan membaca tulisan tersebut dan apa maksud apa tujuannya.

Morsey (dalam Tarigan, 2008:20) mengungkapkan, manfaat menulis adalah untuk merekam, meyakinkan, melaporkan, serta mempengaruhi orang lain dengan maksud dan tujuan agar dapat dicapai oleh para penulis yang dapat menyusun pikiran serta menyampaikan pesan dengan jelas dan mudah dipahami. Kejelasan tersebut bergantung pada pikiran, organisasi, penggunaan kata-kata, dan struktur kalimat yang baik.

Teks prosedur kompleks adalah salah satu kompetensi dasar keterampilan menulis kebahasaan pada siswa SMP/MTs. Dalam standar kompetensi dasar tersebut terdapat kompetensi dasar yang harus dicapai oleh siswa yaitu mampu menulis teks prosedur kompleks melakukan sesuatu dengan urutan yang tepat dengan menggunakan bahasa yang efektif. Informasi yang akan dibahas mengenai menulis teks prosedur kompleks dalam penelitian ini adalah (1) pengertian teks prosedur kompleks, (2) ciri-ciri menulis teks prosedur kompleks, dan (3) langkah-langkah menulis teks preosedur kompleks.

Ciri-ciri teks prosedur kompleks yang baik dan jelas, logis, dan singkat. Jelas adalah bahasa yang digunakan tidak membingungkan dan mudah diikuti, menggunakan nomor untuk membedakan langkah yang satu dengan yang lain, dan dilengkapi dengan gambar. 
Penelitian ini menggunakan metode research and development (R\&D) yang dikemukakan oleh (Sugiono 2010:407). Metode penelitian dan pengembangan adalah metode penelitian yang digunakan untuk menghasilkan produk tertentu dan menguji keefektifan produk tersebut. Metode penelitian ini merujuk pada model Borg \& Gall dengan sedikit penyesuaian sesuai konteks penelitian. Penelitian ini tujuan akhirnya adalah mengembangkan suatu produk yang dapat digunakan dalam pembelajaran. Adapun ruang lingkupnya adalah pengembangan bahan ajar menulis teks prosedur kompleks dengan menggunakan bahan ajar LKS bagi siswa kelas VIII MTs, produk yang dihasilkan berupa bahan ajar LKS menulis teks prosedur kompleks bagi siswa kelas VIII MTs.

\section{Pengembangan Produk}

Pengembangan kemampuan menulis teks prosedur kompleks siswa MTs belum dapat dilakukan secara optimal. Oleh karena itu, diperlukan upaya untuk mewujudkan proses pengembangan kemampuan menulis teks prosedur kompleks ini secara lebih baik. Upaya tersebut dapat dilakukan dengan cara penggunaan produk pendidikan seperti buku yang dapat menunjang pembelajaran. Dengan bahan ajar LKS yang dihususkan pada menulis teks prosedur kompleks maka akan dihasilkan LKS teks menulis teks prosedur kompleks yang berkualitas karena dapat memotivasi siswa untuk lebih aktif dalam pembelajaran.

Borg \& Gall dalam Nana Syaodih Sukmadinata (2006: 169170) memaparkan sepuluh langkah pelaksanaan strategi penelitian dan pengembangan sebagai berikut:

1. Penelitian dan pengumpulan data (research and information collecting) yang meliputi pengukuran kebutuhan, studi literatur, penelitian dalam skala kecil, dan pertimbangan-pertimbangan dari segi nilai.

2. Perencanaan (planning) yaitu menyusun rencana penelitian, meliputi kemampuan-kemampuan yang diperlukan dalam pelaksanaan penelitian, rumusan tujuan yang hendak dicapai dengan penelitian tersebut, desain atau langkah-langkah penelitian, dan kemungkinan dalam lingkup terbatas.

3. Pengembangan draf produk (develop preliminary form of product). Pengembangan bahan pembelajaran, proses pembelajaran, dan instrumen evaluasi.

4. Uji coba lapangan awal (preliminary field testing). Uji coba di lapangan pada satu sampai tiga sekolah dengan enam sampai dengan dua belas subjek uji coba (guru). Selama uji coba dilakukan pengamatan, wawancara dan pengedaran angket.

5. Merevisi hasil uji coba (main product revision).

6. Uji coba lapangan (main field testing). Melakukan uji coba yang lebih luas pada 5 sampai dengan 15 sekolah dengan 30 sampai dengan 100 orang subjek uji coba.

7. Penyempurnaan produk hasil uji lapangan (operasional product revision). 
8. Uji pelaksanaan lapangan (operasional field testing). Dilaksanakan pada 10 sampai dengan 30 sekolah melibatkan 40 sampai dengan 200 subjek. Pengujian dilakukan melalui angket, wawancara, observasi dan analisis hasilnya.

9. Penyempurnaan produk akhir (final product revision).

10. Diseminasi dan implementasi (dissemination and implementation).

Gambar 1. Posisi pengumpulan data dalam penelitian dan pengembangan level 3 (meneliti dan menguji untuk pengembangan produk yang telah ada)
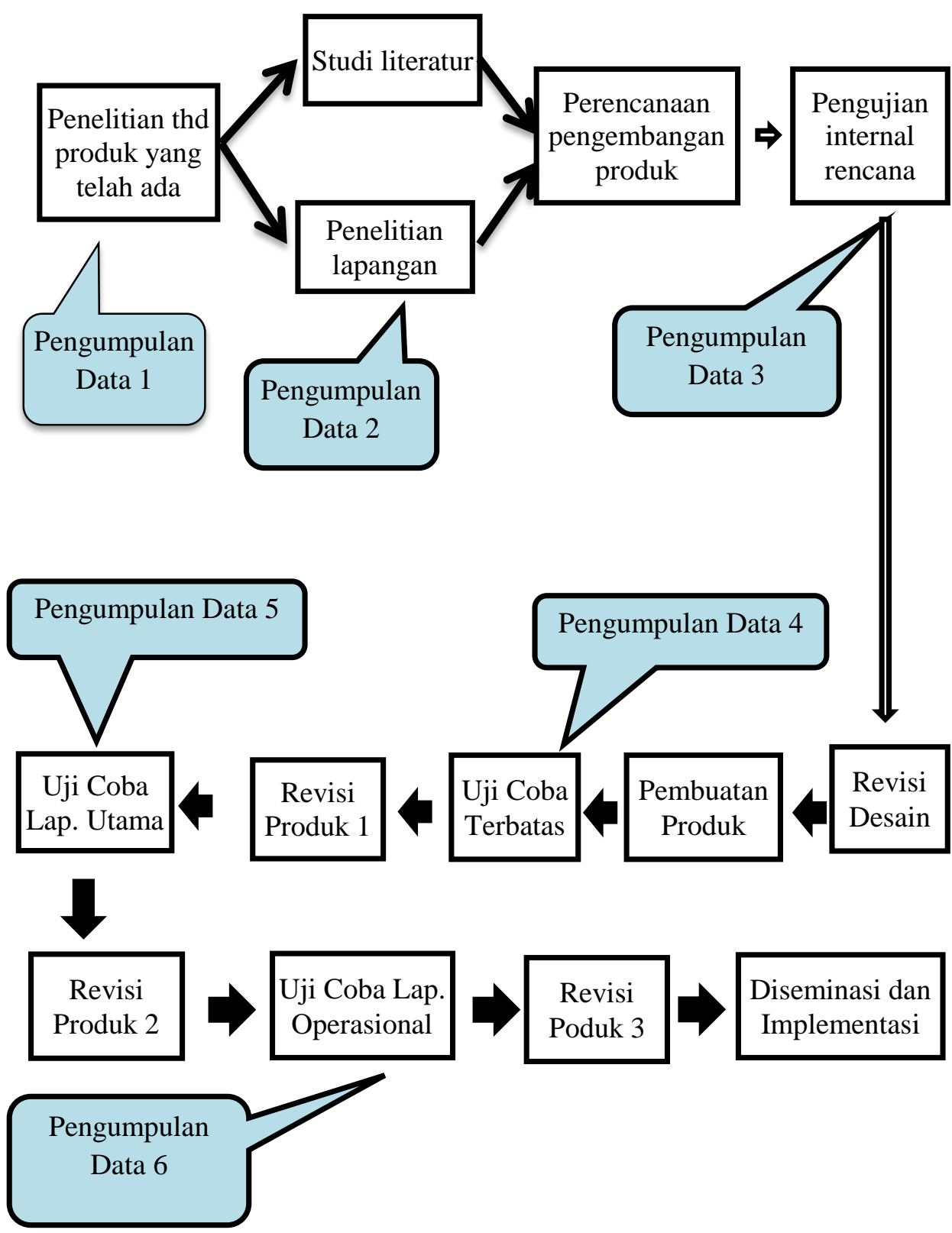

Model Pengembangan merupakan dasar untuk mengembangkan produk yang akan dihasilkan. Model pengembangan dapat berupa model prosedural, model konseptual, dan model teoritik. Model dalam penelitian ini menggunakan model 
prosedural. Model prosedural adalah model yang bersifat deskriptif, menunjukkan langkah-langkah yang harus diikuti untuk menghasilkan produk. Produk yang dikembangkan dalam penelitian ini adalah pengembangan bahan ajar LKS menulis teks prosedur kompleks untuk siswa kelas VIII MTs Miftahul Ulum. LKS menulis teks prosedur tersebut diharapkan mampu meningkatkan pemahaman menulis teks prosedur secara efektif dan lebih meningkatkan hasil belajar siswa. Pengembangan media ini didasarkan pada pengembangan $\mathrm{R} \& \mathrm{D}$. Langkah pengembangan yang dilakukan oleh peneliti adalah : tahap pengumpulan data, tahap pengembangan produk, tahap validasi, tahap revisi, uji coba produk.

Tahap pengumpulan data dilakukan untuk mengetahui kebutuhan pembelajaran di lapangan. Penelitian pengembangan bahan ajar ini dilakukan di MTs Miftahul Ulum, Jarin. Informasi diperoleh dari guru mata pelajaran Bahasa Indonesia dan siswa kelas VIII di MTs. Miftahul Ulum, Jarin. Pengumpulan informasi dari guru dilakukan dengan menggunakan instrumen penelitian berupa wawancara, sedangkan pengumpulan informasi dari siswa dilakukan dengan menggunakan intrumen penelitian berupa angket. tahap pengembangan produk setelah memperoleh data-data yang diperlukan dari guru, siswa dan bahan ajar yang berupa buku paket Bahasa Indonesia, maka langkah selanjutnya adalah tahap pengembangan produk menulis teks prosedur kompleks dengan pendekatan kontekstual. Uji validasi pengembangan bahan ajar LKS menulis teks prosedur yang dilakukan oleh 2 ahli bahan ajar Kuswati, M.Pd dan Nurul Yakin, M.Pd. 2 Guru Bahasa Indonesia (Linear) Maryatun, S.Pd dan Nur Laila S.Pd. Validasi dilakukan untuk menggali informasi terkait kualitas bahan ajar yang dikembangkan. Instrumen validasi berupa angket/kuesioner yang berisi penilaian kelayakan bahan ajar menulis teks prosedur kompleks berdasarkan aspek sampul (cover), isi/materi, dan kebahasaan. Tahap revisi setelah dilakukan validasi oleh ahli bahan ajar dan guru mata pelajaran, maka langkah selanjutnya adalah merivisi produk sesuai dengan anjuran ahli bahan ajar dan guru Bahasa Indonesia. Uji coba produk ini akan dilakukan kepada siswa selaku responden dan juga pengguna untuk mendapatkan informasi mengenai bahan ajar yang berupa bahan ajar tersebut. Uji produk ini akan dilakukan oleh 18 siswa kelas VIII di MTs Miftahul Ulum, Jarin. Berikut ini adalah gambar langkah-langkah pengembangan produk.

Teknik pengumpulan data merupakan upaya peneliti dalam mengumpulkan data yang diperoleh di lapangan. Untuk mendapatkan data-data yang akurat, maka dalam penelitian ini digunakan beberapa metode yaitu angket, wawancara, tes dan validasi.

Sugiono (2015:32-33) secara metodologis, penelitian pengembangan mempunyai empat tingkat kesulitan yaitu: meneliti tanpa menguji (tidak membuat dan tidak menguji produk), menguji tanpa meneliti (menguji validitas produk yang telah ada), meneliti 
dan menguji dalam upaya mengembangkan produk yang telah ada, dan meneliti dan menguji dalam menciptakan produk baru. Sedangkan dalam penelitian ini berada pada level keempat yaitu meneliti dan menguji dalam menciptakan produk baru. Untuk Pengumpulan Data pada Penelitian dan Pengembangan Level 4 (Meneliti \& Menguji dalam Menciptakan Produk Baru) dengan penjelasan sebagai berikut.

\section{PEMBAHASAN}

Data yang diperoleh dari penelitian ini adalah data kelayakan bahan ajar LKS. Data kelayakan bahan ajar LKS diperoleh melalui angket instrument validasi yang divalidasi oleh seorang validator yaitu ahli bahan ajar dan pengguna (guru Bahasa Indonesia).

Rancangan bahan ajar yang sudah selesai dibuat, selanjutnya dilakukan uji validasi. Uji validasi pada bahan ajar ini dilakukan dengan menggunakan instrument validasi yang di dalamnya memuat aspek-aspek penilaian, yaitu aspek sampul, isi/materi, dan kebahasaan. Berikut disajikan data hasil validasi oleh ahli bahan ajar, dan pengguna (guru bahasa indonesia).

a. Validasi Ahli Bahan Ajar

Validasi produk dilakukan oleh dua ahli bahan ajar yaitu Nurul Yakin, M.Pd sebagai ahli bahan ajar 1 dan Kusumawati, M.Pd , sebagai ahli bahan ajar 2. Data hasil validasi yang dilakukan oleh 2 orang ahli bahan ajar LKS meliputi 3 aspek yaitu aspek sampul (cover), isi/materi, dan kebahasaan.

Proses validasi dari kedua ahli bahan ajar akan dilakukan sebanyak 2 kali tahapan. Tahapan pertama yaitu ahli bahan ajar melakukan penilaian terhadap ketiga aspek.

\section{1) Validasi Ahli Bahan Ajar Tahap 1 (Sampul)}

Dalam aspek sampul ini terdapat sembilan komponen penilaian, yaitu (1) Tampilan bahan ajar LKS menarik, (2) Tampilan bahan ajar LKS mudah dipahami, (3) Gambar-gambar yang digunakan pada bahan ajar LKS sudah sesuai., (4) Gambargambar pada bahan ajar tidak mengganggu konsentrasi siswa, (5) Tata letak gambar pada media pembelajaran konsisten, (6) Ukuran gambar pada bahan ajar LKS konsisten, (7) Ukuran teks pada bahan ajar LKS proporsional sehingga mudah untuk membaca, (8) Pemilihan warna teks dengan bacground pada bahan ajar LKS sesuai, dan (9) Jenis huruf (font) yang digunakan pada LKS mudah dibaca.Untuk memperoleh gambaran penilaian ahli bahan ajar mengenai penyajian sampul (cover) dalam bahan ajar menulis teks prosedur kompleks.

Berikut hasil penilaian uji coba lapangan terbatas yang dilakukan oleh 5 orang siswa.

Tabel 1. Uji coba lapangan terbatas

\begin{tabular}{|c|c|c|}
\hline \multirow{2}{*}{ Nilai } & \multicolumn{2}{|c|}{ Indikator Penilaian } \\
\cline { 2 - 3 } & Susunan kalimat & Kalimat efektif \\
\hline Skor Rata-rata & 4.00 & 2.80 \\
\hline Persentase & $100 \%$ & $70 \%$ \\
\hline Kategori & Baik & Cukup \\
\hline
\end{tabular}


Tabel 2. Uji coba lapangan utama

\begin{tabular}{|c|c|c|}
\hline \multirow{2}{*}{ Nilai } & \multicolumn{2}{|c|}{ Indikator Penilaian } \\
\cline { 2 - 3 } & Susunan kalimat & Kalimat efektif \\
\hline Skor Rata-rata & 3.77 & 3.22 \\
\hline Persentase & $94.4 \%$ & $80.5 \%$ \\
\hline Kategori & Sangat Baik & Sangat Baik \\
\hline
\end{tabular}

SIMPULAN
Berdasarkan uraian hasil penelitian dapat dikemukakan simpulan yang berkaitan dengan pengembangan bahan ajar LKS menulis teks prosedur kompleks bagi siswa kelas VIII MTs.

1. Berdasarkan analisis terhadap kebutuhan bahan ajar menulis teks prosedur kompleks, siswa dan guru membutuhkan bahan ajar menulis teks prosedur kompleks yang ditulis secara praktis, efektif dan mudah dipahami oleh siswa. Selain itu, siswa dan guru menginginkan LKS atau bahan ajar yang didesain dengan kemasan yang menarik, praktis, dan sesuai dengan pemahaman siswa.

2. Berdasarkan hasil analisis angket, respon siswa dan wawancara dengan guru Bahasa Indonesia, terdapat masukan atau saran yaitu pada penataan warna, gambar, maupun tulisan pada sampul depan LKS ditempatkan pada posisi yang sesuai agar terlihat menarik, sedangkan untuk materi pada bahan ajar LKS harus menggunakan bahasa yang efektif agar mudah dipahami oleh siswa. Petunjuk penggunaan LKS diletakkan sebelum Bab 1. Isi dalam LKS ini adalah materi pengertian menulis teks prosedur kompleks, ciri-ciri yang perlu diperhatikan dalam menulis teks prosedur kompleks, kalimat efektif, langkahlangkah menulis teks prosedur kompleks, dan contoh-contoh menulis teks prosedur kompleks, Selain materi, bahan ajar menulis teks prosedur kompleks ini juga dilengkapi dengan latihan-latihan soal, tugas.

3. Nilai rata-rata yang diberikan oleh dua ahli bahan ajar dan dua penggguna yaitu guru Bahasa Indonesia. Dari kedua orang ahli bahan ajar yang menilai bahan ajar LKS menulis teks prosedur kompleks, yaitu (1) aspek penyajian sampul (cover) dari ahli bahan ajar 1 mendapatkan skor sebesar 4.22 sedangkan dari ahli bahan ajar 2 mendapatkan skor sebesar 4.22 dan termasuk dalam kategori "Baik", (2) aspek isi/materi dari ahli bahan ajar 1 mendapatkan skor rata-rata 4.14 termasuk dalam kategori "Baik", sedangkan ahli bahan ajar 2 mendapatkan skor ratarata 4.28 dengan kategori "Sangat baik'(3) aspek kebahasaan dan keterbacaan mendapatkan skor rata-rata 4.00 termasuk dalam kategori "Baik", sedangkan ahli bahan ajar 2 mendapatkan skor rata-rata 4.375 dengan kategori "Baik". Sedangkan dari ahli pengguna dari aspek (1) Aspek sampul (cover) dari ahli pengguna 1 mendapatkan skor rata-rata 4.00 termasuk dalam kategori "Baik", sedangkan pengguna 2 mendapatkan skor rata-rata 4.00 dalam kategori "Baik". (2) Aspek Isi/materi ahli pengguna 1 mendapatkan skor rata-rata 
4.00 dalam kategori "Baik", sedangkan pengguna 2 mendapatkan skor rata-rata 4.2 dalam kategori "Baik". (3) Aspek kebahasaan ahli pengguna 1 mendapatkan skor rata-rata 3.75 dalam kategori "Baik", sedangkan pengguna 2 mendapatkan skor rata-rata 4.00 dalam kategori "Baik".

4. Setelah melakukan perbaikan-perbaikan berdasarkan hasil penilaian dan saran oleh ahli bahan ajar dan pengguna, maka bahan ajar menulis teks prosedur kompleks setelah perbaikan berisi materi pengertian menulis teks prosedur kompleks, ciriciri yang perlu diperhatikan dalam menulis petunjuk, langkahlangkah menulis teks prosedur kompleks, contoh menulis teks prosedur kompleks, dan kalimat efektif. Seluruh materi akan disusun dalam 3 materi, materi I: mengenal teks prosedur kompleks, materi II: menulis teks prosedur kompleks dengan bahasa yang efektif, materi III: contoh dan langkah-langkah menulis teks prosedur kompleks. Bentuk LKS bahan ajar menulis teks prosedur ini dikemas dengan ukuran A4 dengan jumlah halaman 21 dan ukuran huruf 12. Sampul depan bahan ajar menulis teks prosedur kompleks ini berisi nama penulis, judul LKS, ilustrasi gambar siswa sedang membaca dan urutan gambar melakukan sesuatu.

\section{DAFTAR PUSTAKA}

Fadila, Anisa. 2011" Pengembangan Bahan Ajar LKS Menulis Karangan Narasi dengan Pendekatan Kontekstual bagi Siswa Kelas X SMA". Skripsi. Universitas Negeri Semarang.

Iskandar. 2009. Metode Penelitian Kualitatif. Jakarta : Gaung Persada Press.

Kosasih, E. 2009. Petunjuk Guru Bahasa Indonesia untuk SMP Kelas VII. Bandung: CV. Cipta Dea Pustaka.

Lestari, Ika. 2013. Pengembangan Bahan Ajar Berbasis: Sesuai dengan Kurikulum Satuan Pendidikan. Padang: Akademia Permata.

Luthfan, 2015. Contoh Teks Prosedur Kompleks. dalam http://wwLuthfan,Diakses 07
Nurgiyantoro, Burhan. 1995. Teori Pengkajian Fiksi. Yogyakarta: Gadjah Mada University Press.

Prastowo, Andi. 2012. Panduan Kreatif Membuat Bahan Ajar Inovatif. Yogyakarta: Diva Press. 2013.

Panduan Kreatif Membuat Bahan Ajar Inovatif. Yogyakarta: Diva Press.

Purwoko, Prida. 2013. Pengembangan Bahan Ajar Berbasis Lembar Kerja Siswa. dalam http://wwPridaPurwoko. Diakses 07 Februari 2018 pukul 13:22

Sugiyono, 2011. Metode Penelitian Kuantitatif Kualitatif $R \& D$. Bandung: Alfabeta. 2012. Prosedur Penelitian Suatu Pendekatan Praktik. Jakarta : PT. Rineka Cipta.

Suyanto, Edi 2015. Membina, Memelihara dan Menggunakan Bahasa Indonesia Secara Benar. Graha Ilmu. 
Tarigan, Henri Guntur 2008. Membaca sebagai suatu keterampilan berbahasa. Bandung: Angkasa.

Tryanasari, Nova Paramytha. 2009. "Pengembangan Bahan Ajar LKS Menulis Resensi dengan Tehnik Cutting And Glowing Bagi Siswa SMP kelas IX'.Skripsi. Universitas Negeri Semarang.
Widyowati, Pengembangan LKS Menulis Resensi Buku dengan Pendekatan Kontekstual bagi Siswa SMA". Universitas Negeri Malang. 